should be made to teach students how to prescribe glasses." Paterson does not advocate examination in ophthalmology. He would be content if students were made to realize that they could not be granted a class certificate unless they had a satisfactory knowledge of diseases of the eye.

Briefly, then, the writers of the articles noticed above agree that (1) ophthalmology should form an essential part of the students' curriculum; (2) no attempt should be made to treat the subject of refraction seriously; (3) the use of the ophthalmoscope should be obligatory; and (4) clinical demonstrations should be substituted for formal lectures.

\title{
An American School of Military Ophthalmology
}

With their usual foresight our American allies have instituted at Fort Oglethorpe, Ga., a school of military ophthalmology, which has been in working order since August, 1918. The underlying idea is to train eye men and others who have entered the service in military ophthalmology, more especially as it is practised overseas. Lieut.Colonel G. E. de Schweinitz (Amer. Jl. of Ophthal., December, 1918) has given an interesting account of the organization and development of the institution, which is in connection with U.S. General Hospital No. 14. A new building of two stories has been placed at the disposal of the school. The first floor includes refraction rooms, stalls for retinoscopy and ophthalmoscopy (in one of which a lantern screen can be readily adjusted), a room for the purposes of the optician, which also serves as a place for the clinical clerk to take the patient's history and record the preliminary visual tests, and a covered porch which, in suitable weather, is used as a waiting room. The first floor also contains a room for operations upon animals' eyes, a small theatre for such operations upon human eyes as do not call for the administration of a general anaesthetic, and rooms for the Chief of Service and the storing of records. The space still remaining is fitted as a ward of sixteen beds. The second floor of the building is occupied by beds (should such be needed), together with the usual offices connected with a sick ward. The operating theatre of the neighbouring Oto-Laryngological building is used for operations upon the eye which require a general anaesthetic. An entrance examination must be passed before an officer is admitted to the School of Ophthalmology. At the end of each four weeks' course the students are graded according to a report from the instructors after a written and oral examination. The Director of the School determines the degree of proficiency of each student, and it is upon this that the officer's ultimate retention for eye work in the Army is based. The staff of the School consists of 
Major Meyer Wiener, as Director and Chief of Service, and of eight instructors, selected on account of their records as teachers and practical ophthalmic surgeons prior to entering the Medical Corps of the American Army. Material is obtained from several sources : (1) the regular dispensary service of U.S. General Hospital, No. 14, (2) patients from the eye ward of the same hospital, (3) recruits examined elsewhere, and (4) patients in the general medical, surgical, and neurological departments of the General Hospital. At the present time between 500 and 600 patients attend the School per month. The length of the course is four weeks, and it includes the teaching of refraction, muscle and other functional testing, anatomy and histology of the eye and its appendages, external diseases, ophthalmoscopy, operations, and ophthalmic neurology. Liberal use is made of the lantern, diagrams, freehand drawings, and microscopic slides. A feature of importance is the work done in co-operation with the other departments of the General Hospital, notably those of anatomy, surgery, otolaryngology, X-rays, pathology, and bacteriology.

\section{ABSTRACTS}

\section{I-INCONGRUENCE IN HEMIOPIA}

Rönne (Copenhagen).-On incongruence and asymmetry in homonymous hemiopia. (Ueber die Inkongruenz und Asymmetrie im homonym hemianopischen Gesichtsfeld.) Klin. Monatsbl. f. Augenheilk., A pril-May, 191 5, p. 399.

Rönne's article deals with the interesting and difficult subject of the relationship of lesions of the optic paths to changes in the visual fields, especially in regard to the presence of incongruence in hemiopic fields.

It is generally accepted that corresponding retinal points are represented by "point centres" in close juxtaposition in one or other occipital lobe. Such an arrangement does not exclude the possibility of incongruence, and it is of great theoretical and practical interest to know in what circumstances we may expect it. Various types of incongruence may occur:

1. Incongruence due to errors of observation in perimetry. This may be avoided by using a series of test-objects.

2. True incongruence is present when the lesion is at a part of the optic path where the fibres from corresponding retinal points are not yet associated. This is more likely to be the case the further 